DOI: $10.2478 /$ ausae-2014-0015

\title{
Improving the urban green system and green network through the rehabilitation of railway rust areas
}

\author{
Dóra HUTTER, ${ }^{1 *}$ Kinga SZILÁGYI ${ }^{1}$ \\ ${ }^{1}$ Department for Garden and Open Space Design, Corvinus University of Budapest, \\ Faculty of Landscape Architecture, Budapest-1118, Villányi St. 35-43. \\ dora.hutter@uni-corvinus.hu, (*corresponding author),kinga.szilagyi@uni-corvinus.hu
}

Manuscript received 27. 08. 2014; revised 12.09. 2014; accepted 20. 09. 2014

\begin{abstract}
The Industrial Revolution had a negative impact on both the city and the environment. By the second half of the $19^{\text {th }}$ century, the urban erosion of industrial cities cried for direct intervention and curing. The methods developed either along an urban or an anti-urban philosophy: they resulted in the new models of green belt systems aimed at solving all the main urban problems with restructuring the urban fabric, controlling the urban spread into the rural landscape, the lack of green areas and open spaces for recreation and social life, and the lack of green spaces for ventilation. Nowadays, the major cities and capitals around the globe are competing for titles such as healthier, more liveable or even greener city. Given the unfortunate attributes of the urban structure in the historical cities, the development of new transportation sites or green areas is an extremely difficult issue. On the other hand, in the big cities, the brownfield sites are considered as reserve areas for sustainable urban development. Reusing the brownfields and rust areas is already a land saving urban development approach and in case of a complex and ecological urban rehabilitation it can underlie the development of an efficient urban green system and green network.
\end{abstract}

Keywords: brownfield development, urban green system, green network, railway rust belt rehabilitation

\section{Introduction}

The aim of our research was to identify those rust areas that hold potentials for green surface development following the principles of sustainable and ecological urban development. The linear structural elements of the railway network can replace the missing elements of the ring-radial urban green system. Therefore, among the various brownfield rehabilitation possibilities, we were focusing on the formal railway sites. After reviewing the literature on the urban 
green system of Budapest and its railway rust areas, we established the following research hypothesis: How can brownfield rehabilitations improve the urban green system and the green network connections?

To answer this question, our first step was to prepare the cadastre map of the railway rust areas by comparing orthophotos with the development plans (realignment plans for the railway network, selected areas to be vacated) of the Hungarian State Railway (MÁV Zrt.). Among the current railway areas in Budapest, the following sites could be recommended to be reused:

1. the underutilized, almost functionless, or abandoned sites;

2. sites that are not involved in the future development plans of $M A ́ V$;

3. sites that can be integrated into the urban structure due to their adequate size or location.

Having prepared the first cadastre map, we compared the two networks and studied the relations between the green network and the railway rust areas. After further ground truthing and analysis of the land use maps, we determined the development potential based on a $4^{\text {th }}$ criterion:

4. which railway rust areas are valuable due to their size or location and hold significant green surface potentials?

Finally, we conducted an analysis from an ecological perspective so we could identify those rust areas that have good attributes for green surface development. Based on the vegetation index assessment, near-infrared orthophotos and multiple ground truthing, we can determine:

5. the proportion of biologically active green surfaces in the railway rust areas and the ecological value of the established vegetation

The detailed analysis of the vegetations will be presented on a selected, representative area. Due to its diversity and complexity, it will provide an insight into the degraded habitats and green surfaces established on the rust areas.

Based on the above described criterions, we will make suggestions for the possible land use categories and new functions for potential railway rust areas. Making an example of Budapest, we will demonstrate on a schematic map how the rehabilitated rust areas can support a well-established ring-radial green network, the development of a well-functioning green network, and broaden the urban recreational facilities.

\section{The role of green system in urban ecology}

The first comprehensive urban green system plan in Hungary was prepared in the 1960s. It reviewed the various elements of the green surface of the capital and the agglomeration, with the prospect of joining them together in a more united and coherent system. The so-called MÉM Green Belt Concept Plan was mainly 
focusing on agricultural production, having carried out a significant afforestation programme. However, though it resulted in a well-structured optimal - from the landscape architectural, urban structural and urban ecological aspects - ring-radial green system, there were several new green-space developments based on this plan in the next two decades, mainly in connection with the afforestation programme on the Pest-side. After all, by the end of the 1980s, it was obvious that the once realistic urban development objective would not be feasible, and the urban green system had become mosaic [1]. The green surface policy in the 1970s included the $60 \%$ guideline. We intend to achieve that within the urban inner area the green surface proportion would reach $60 \%$ [2]. Perhaps this planning principle was not so idealistic back in the 1970s. The first green surface balance of Budapest was prepared for the Environmental Protection Concept in 1982. In the early 1980s, within the administrative boundary of the capital (and not only within the inner area), this green surface proportion still reached the $60 \%$. As a consequence of the urban developments in the last decades, it has been constantly decreasing. The last survey was conducted in reference to the Pro Verde Budapest (the development concept and programme for the green system of Budapest), when they analysed satellite images taken in 1990 and 2005 [3]. The speculative green surface proportion in 1990 was recorded as $51 \%$ and by 2005 it reduced to $48.7 \%{ }^{1}$ From this tendency, we assume that today the overall green surface is unfortunately even below $50 \%$. Considering the overall green surface decrease, it seems a rather drastic diminution: $11 \%$ in 27 years. $^{2}$

Nevertheless, the urban heat island phenomenon has been intensified in the past decades. Regarding the urban climate of Budapest, we can see minor changes in the last 100 years, but in the last three decades the warming tendency has been stronger. ${ }^{3}$ This change is obviously not only the consequence of the decreasing green surface area, but there are several other factors including:

- changes in the macro-climate and, as a result, the intensification of the continental character in the climate of Hungary;

- changes in the urban energy import, mainly an increasing road traffic.

1 To examine the condition of the green surfaces of Budapest, we used the satellite images taken on 23 July 1990 and 1 August 2005 by the Landsat 5-satellite. The assessment was based on the NDVI values obtained from red and near-infrared layers.

2 Undoubtedly, the accuracy of the general balance based on the average green surface index and the NVDI values obtained through digital assessment could not be compared. If we compare the green surface proportions obtained from the same assays $(51 \%$ in 1990 , $48.7 \%$ in 2005) with the urban development, it is probable that the balances prepared back in the 80 s presented slightly better proportions since the expansion of the city was not so intensive that it would have resulted in a $9 \%$ decrease in 10 years, especially if we compare it to the $2.3 \%$ decrease occurring in the 15 years from 1990 .

3 Changes in the annual average temperature between the 1900 and the 2000 OMSZ report. 
- decreasing the biologically active green surface proportion of the city, as a quantitative alteration;

- changes in the quality of the biologically active green surfaces, deterioration of the conditioning effect of the green surface network caused by the decreasing green surface intensity, the decaying vegetation and the over-fragmented system.

\section{Brownfields and rust areas in the urban structure}

Various rust areas are considered as valuable sites in our crowded, overbuilt cities with a mosaic structure. After the political changes of the $90 \mathrm{~s}$, the expanded industrial areas with their belongings, such as public utilities and transport area, have lost their original functions. Nowadays, these occupy large and valuable areas and cut off important urban linkages. ${ }^{4}$ The reuse of these underutilized areas aids the land-saving urban-development and the green space development projects.

More than $13 \%\left(68 \mathrm{~km}^{2}\right)$ of the administrative boundary of Budapest is considered a brown zone, while if we compare it to the built-up area it is $30 \%$. Within a few areas, the rehabilitation process has already started, or it has already been completed; so, the real problem remains the so-called rust belt.

The brownfield sites are not always abandoned, ruinous areas that have lost their functions. In some cases, there is still business activity, new companies and ventures open or close and there are ongoing changes along with the reminiscence of the former enterprises that have gone bankrupt and closed long ago. Still, this area plays a vital part in the economy of Budapest, but maintaining an updated cadastre map of the extensive and large rust areas is difficult and it demands a tremendous work. Based on their location, we can divide them into three main regions: 1-northern, 2-eastern and 3-southern (Fig.1) [4].

\footnotetext{
${ }^{4}$ The term brownfield was first mentioned in the American terminology and, firstly, it only referred to the abandoned industrial areas. Since then, it has gained new meanings and several different definitions have been published. There are certain publications that merely focus on the terminology itself but without giving any final classification. Having said that, in this article, we will use the following definitions based on the common terminology of the Hungarian research studies: brownfield area: usually classified as an area that has fully or partly lost its function, underutilized and abandoned; former industrial or military areas with their transportation facilities that might have real or perceived contamination problems; unsettled proprietary relations and legal regulation, and the numerous small real estates. The above specified brown areas together form a brown zone. Rust belt: consists of the unused and abandoned industrial sites - with the former facilities or transport areas that have fully lost their functions and are unlikely to be restored (Barta 2004).
} 


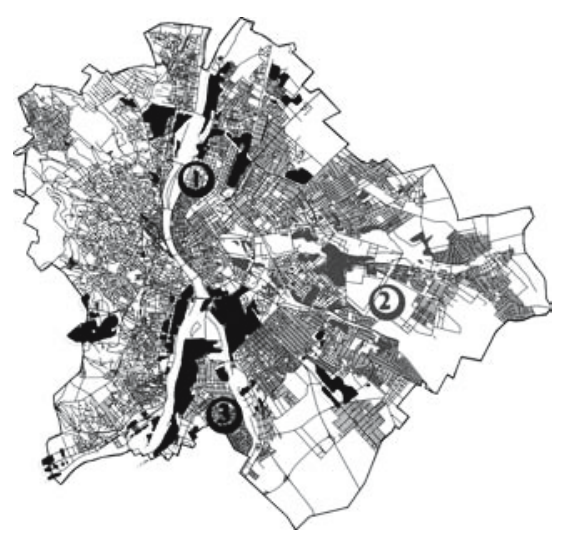

Fig. 1. The 3 major regions of the Budapest brownfield zone (Beluszky, Győri 2004)

Transport, as any other element of the infrastructure, generates development in a city. It provides public transport, logistics, and creates military and communicational possibilities, resulting in an increasing population and in an expanding urban area. From the second half of the XIX century, one of the most dominating impacts on the urban structure was the railway itself. There is a strong relation between the expanding industrial sites and the developing railway network. As a result, the current brownfield areas are located along the railway network.

\section{Relations between the railway system and the green network}

Speaking of either a railway network or an urban green system, in a wellfunctioning network, the nodes consist of smaller-larger areal elements and are connected by lineal segments. The resulting coherent system is built up from such elements that each serves unique functions. A good example is the railway network that could be characterized with the following components: (Tab.1)

Correspondingly, the green system and the green network ${ }^{5}$ consist of linear and areal elements (Tab. 2).

5 'Green network: is the network of open spaces with characteristic vegetations that are with or without minor restrictions - open for the public' [5]. 
Tab. 1. The components of the railway network

\begin{tabular}{ll}
\hline $\begin{array}{l}\text { RAILWAY SYSTEM } \\
\text { linear elements }\end{array}$ & areal elements \\
\hline $\begin{array}{l}\text { industrial trails } \\
\text { loading platform } \\
\text { public transport trails } \\
\text { railway platform } \\
\text { buffer zone along the railway }\end{array}$ & $\begin{array}{l}\text { railway crossing, delta areas } \\
\text { transfer trails, storage trails } \\
\text { transfer station } \\
\text { train station, stopping-place }\end{array}$ \\
railway bridge & $\begin{array}{l}\text { terminal buildings, train shed, repair workhouse, other } \\
\text { railway buildings }\end{array}$ \\
elevated railroad & railway industrial zone \\
railway embankment & railway 'fallow' \\
railway cutting & \\
access road network & \\
mosaic brownfield areas along the railway & \\
linear elements & areal elements \\
access industrial railway & transformational, developing brownfield areas \\
access road network & functioning industrial areas \\
& included residential areas \\
& industrial rust belt \\
\hline
\end{tabular}

Tab. 2. The components of the green system and green network

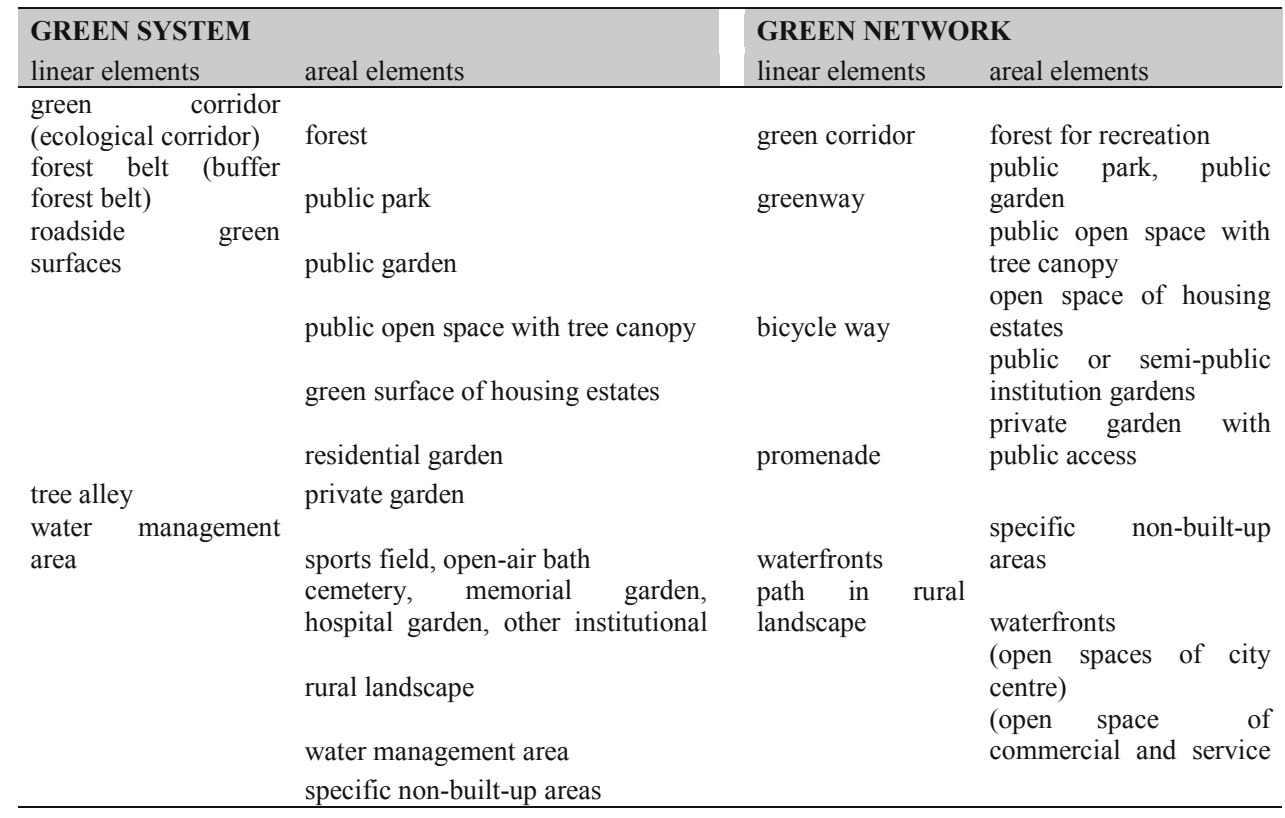


Through transforming the abandoned sites of the railway network (making use of their original structural features), we can improve the urban green system by replacing the missing linear elements or nodes. National and international examples prove that theme parks, institutional gardens, public parks or other linear green elements developed from brownfields draw attraction and hold increasing tourist potentials due to the fresh and modern design approach that exploits the unique features of such particular sites. As a new recreational area, green network element or just as a conditioning surface, they can become valuable elements of the settlement's recreational green network and its complex green system.

A brownfield rehabilitation project can bring urban ecological benefits even if the objective of the particular investment is not to create a new green area or green elements. Through any complex brownfield development - in addition to the renewal of buildings - the development also improves the environment and revitalizes the open spaces. Thus, it provides better environmental quality. The rehabilitation would also improve the climatic characteristics of the site and it would at least minimally increase the biologically active surface proportion and improve the quality of the green surface. All in all, such rehabilitation is beneficial from the urban ecological perspective. The new land use, the type and density of the buildings will determine the foreseeable beneficial impacts on the ecological attributes.

\section{International overview}

In the past decades, the revitalization of the abandoned industrial and transportation sites has been one of the most significant elements in the urban development programmes of any major city, especially in those where the economic transformation resulted in the degradation of the valuable elements in the urban structure and where sustainability and liveability are among the top priority issues. "In Europe, the greening movement has been playing a central role in the sustainable urban development process. Between 1988 and 1993, more than 19\% of brownfield and derelict sites in Britain were converted into green spaces" [6, 7]. The renewal of the obsolete or abandoned railway lines as open space or linear green element was first realized in Paris back in the 1990s. The unique and notable rehabilitation of the former line that runs through the city centre provides an intensely planted, biologically active green promenade (Promenade Plantée) [8]. The green path runs through the crowded city, mostly in a cutting, planted with extensive species and sometimes even several meters above the ground, disengaging the individual from the urban environment [9]. However, the most famous and spectacular rehabilitation project today is the Highline in New York. The former industrial area and the 10-m-high, 2.3-km-long elevated railway track have been transformed into a greenway. In the USA, with state fund and urban cooperation, the former area in downtown Los Angeles was also revitalized. 
Including almost 40 acres, the new park recreated a "riparian habitat in the heart of the bustling metropolis, complete with playgrounds, outdoor classroom facilities and picnic facilities" [10]. These international examples of landscape architecture are inspiring previews for future developments of urban green structure and green network with comparable attributes.

\section{Materials and methods}

The aim of our research was to present those railway rust areas that are potential for rehabilitations from an urban ecological perspective. Our methodology was based on two parallel examinations. We analysed various urban plans and maps comparing them with near-infrared orthophotos. ${ }^{6}$ This enabled us to prepare cadastre maps, study the relations between the networks and define the potential development directions. Further on, we conducted multiple ground truthing and attended various professional exhibitions (conferences, forums), and prepared a more accurate computer analysis.

Preparing the cadastre map of the railway rust areas

Analysing the development of the Budapest railway system, its part in the urban structure and its decreasing importance, we can recommend the following areas for rehabilitation:

1. that are underutilized or totally abandoned

2. that are not involved in the future development plan of MAV (Hungarian State Railways)

3. that can be integrated into the urban structure due to their size or location

On Fig. 2, we marked out these areas and the entire brownfield zone, the frame of which is provided by the railway network. Our mapping was based on our three primary criterions. It provided the ground for further research on the possibilities to improve the urban green system. Overlaying the important elements of the green network, we can observe their relations to the urban structure.

${ }^{6}$ Regulation map of Budapest, Settlement development Concept of districts, Urban Planning Concept of districts, Realignment plans for the railway network, Brownfield zone of Budapest [11], Bicycle route map of Budapest, 2009. 


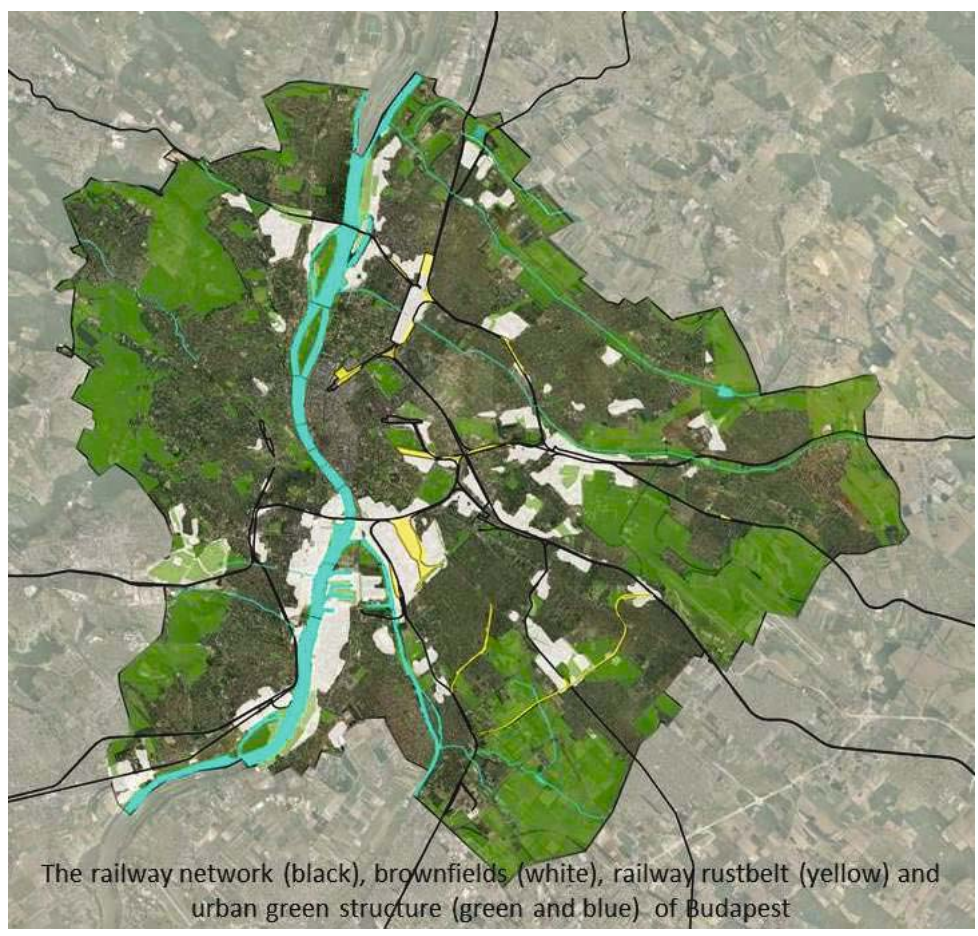

Fig. 2. Railway network, brownfields together with the green system of Budapest (source: Hutter 2012)

Nature reclaims the abandoned and derelict sites through spontaneous occurrence. Mostly adventive, urbanophil species find habitat on the disturbed, usually contaminated sites. The biological activity of the 'urban fallow' is still better and even shows an increasing tendency comparing to the former industrial sites or service areas. On the urban scale, in the context of green network, the "greening rehabilitation" of the rust areas - and specifically the railway rust areas can create new, ecologically balancing open spaces and linear/aerial green elements that are suitable for recreation. These are created exactly in those urban zones where structural elements or other local features are missing. Based on sustainability and liveability principles and overlaying the rust areas and the urban green system, we can investigate:

which railway rust areas hold potentials for significant green surface development due to their size or location?

We selected more than 20 potential areas with diverse characteristics. We analysed their ecological and green surface values to identify those that hold the most potentials from urban ecological perspective (see Fig. 3). 


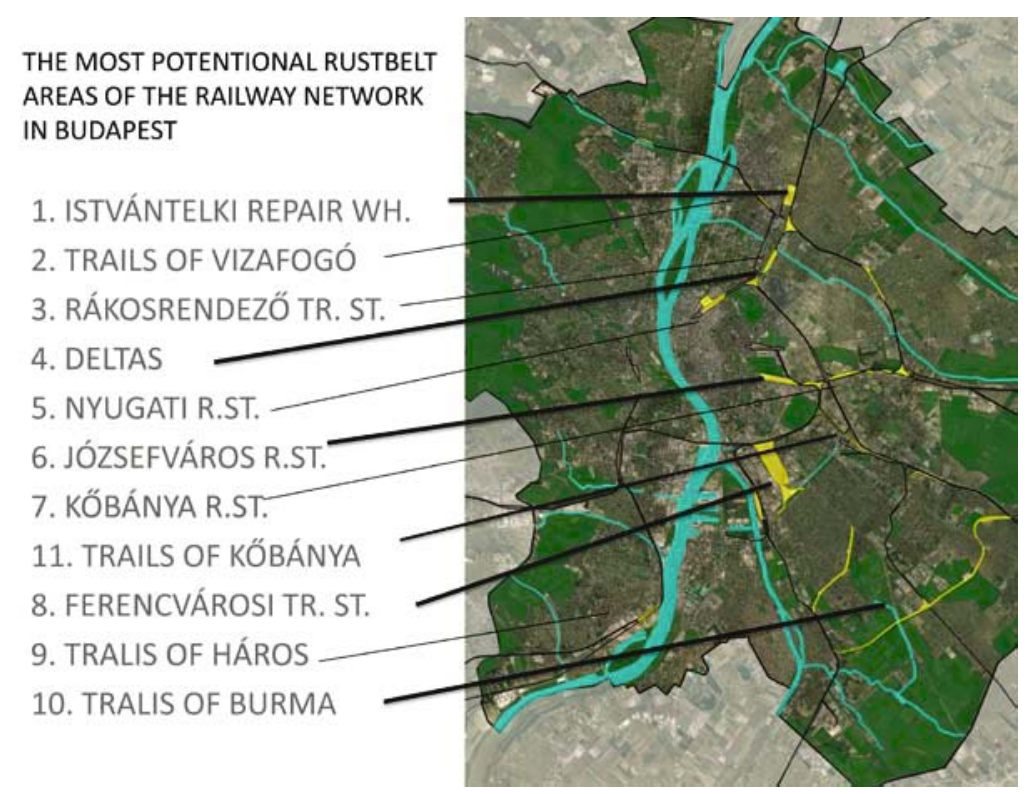

Fig. 3. The potential railway rust areas of Budapest (Hutter)

In the present study, the northern sector will serve as a representative area where a comprehensive assessment was conducted. Focusing merely on the northern sector, we also indicated the industrial rust areas along the railway network. We have studied the extremely detailed previously prepared cadastre maps [11, 12], which we updated using aerial photos and reviewing urban development plans. Figure 4 clearly demonstrates the mosaic distribution of the brownfields, the most significant green surface and green network elements, and the relations between the two networks.

Along the fundamental Northern railway line (Bp. Nyugati pályaudvar - Vác) and the crossing Circle lines, ongoing developments and constructions are altering the urban structure. The transformation of the industrial sector has resulted in underutilized, abandoned and derelict rust areas. There are several former brownfield sites with good transportation facilities and optimal location that have already been rehabilitated, transformed (or taken over by industrial use). In the representative area, we can find both linear and areal elements among the abandoned railway areas. We have thoroughly analysed the nearby industrial rust areas and those blocks that are already under transformation or reconstruction. Afterwards, we compared the underutilized sites with the elements of the urban green system and the green network. The occasional inclusions of various green surface elements in the surrounding brownfield zone hold particular potentials. The most valuable ecological network elements in our representative area are: the 
Danube shore and islands, FOKA Bay, Rákos-creek, Szilas creek, Városliget (City Park), Hungarian Railway Museum (Vasúttörténeti Park), the various neighbourhood parks, public gardens, sports fields and the forests located on the urban boundary. The lack of essential linear elements that would provide optimal connections can be clearly observed. Therefore, it would be important to make use of the various features provided by the structure of the railway network. The aim to improve the green network is supported by the fact that the waterfronts in Budapest hold even more potentials regarding the urban green system and the green network.

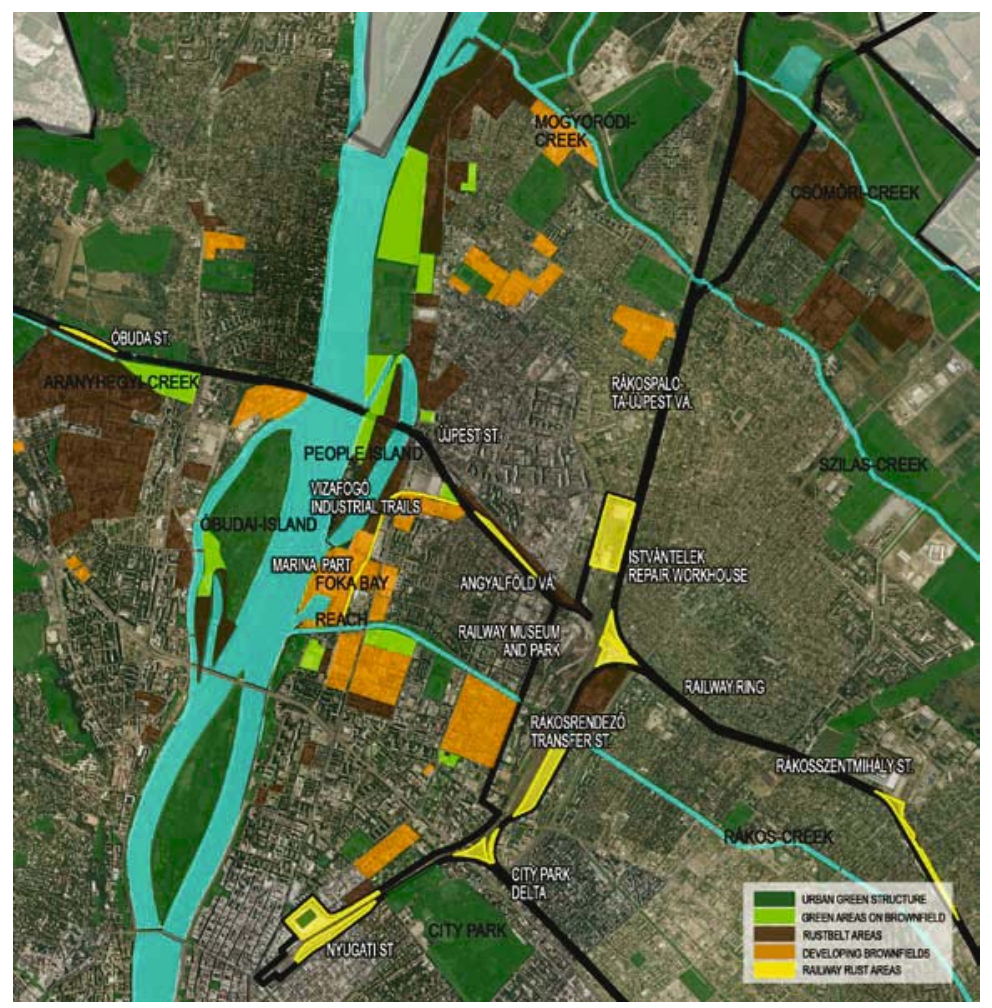

Fig. 4. The railway network and the green system along the northern trails (Hutter)

Subsequently, we also need to consider the ecological attributes and values of the sites, and include them into our criteria, while also analysing the previously selected areas from this aspect. We need to evaluate where we can find an established vegetation; which site could preserve its local green surface characteristics, or where we can detect valuable vegetation cover or significant tree canopy. 
Vegetation assessment along the railway rust areas

Redeveloping or reusing the rust areas is an important mean of urban development, which generally improves the environmental quality. The various rehabilitation objectives and principles in Hungary unfortunately hardly consider the ecology, urban ecology or green surface. Our research study, therefore, aimed at making an evaluation and recommendations based on these ecological principles.

Thus, our next step was to analyse near-infrared orthophotos and the vegetation index of the areas and try to determine the changes occurred since 1990. Analysing various maps and databases $[3,13,14]$ and conducting multiple ground truthing, we have updated and improved the inventory (see Fig. 5). Finally, we formulated the following research thesis:

What are the biologically active green surface proportion and the ecological value of the established vegetation in the railway rust areas?
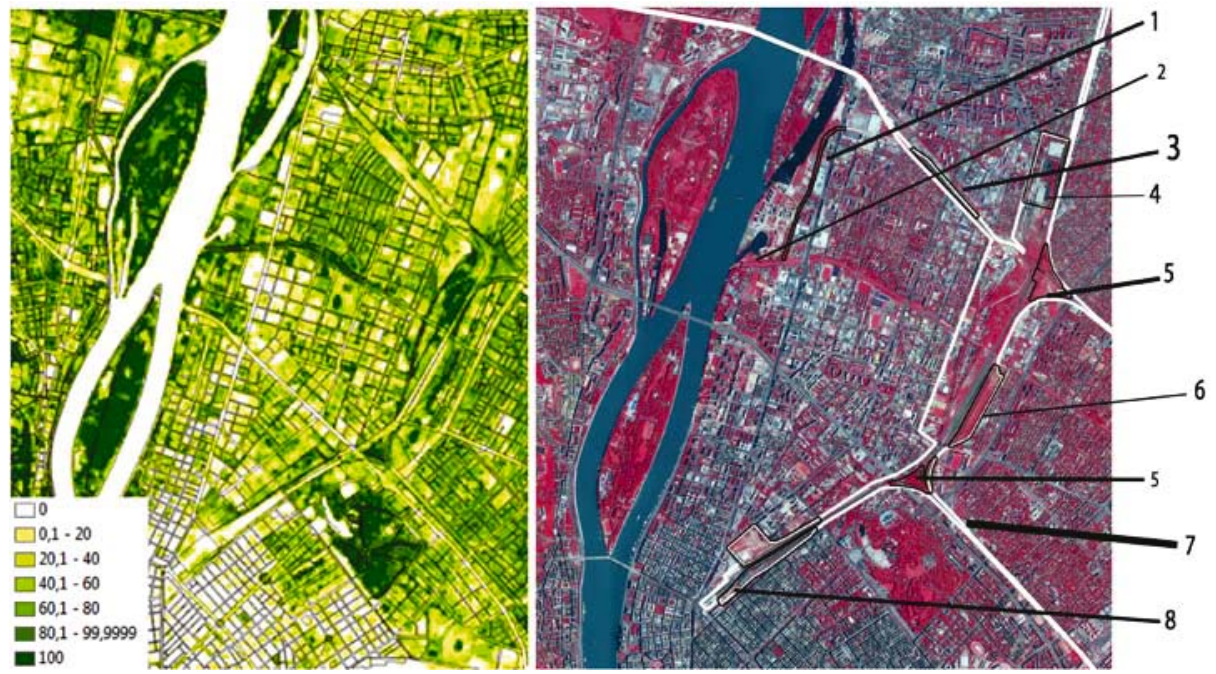

Fig. 5. Vegetation Intensity Map, $2013^{7}$ (Jombach 2012); Near-infrared orthophoto, 2010 (FÖMI - Institute of Geodesy, Cartography and Remote Sensing, Hungary)

The representative area in the northern region introduces various characteristics and shows a great diversity of vegetation. We have chosen 8 sites with different characteristics that are connected by the railway network and we studied the established local vegetation (see Fig. 6).

\footnotetext{
${ }^{7}$ We have used the following satellite images: 19/05/2013; 22/07/2013; 07/08/2013 made by the Landsat 8 satellite.
} 

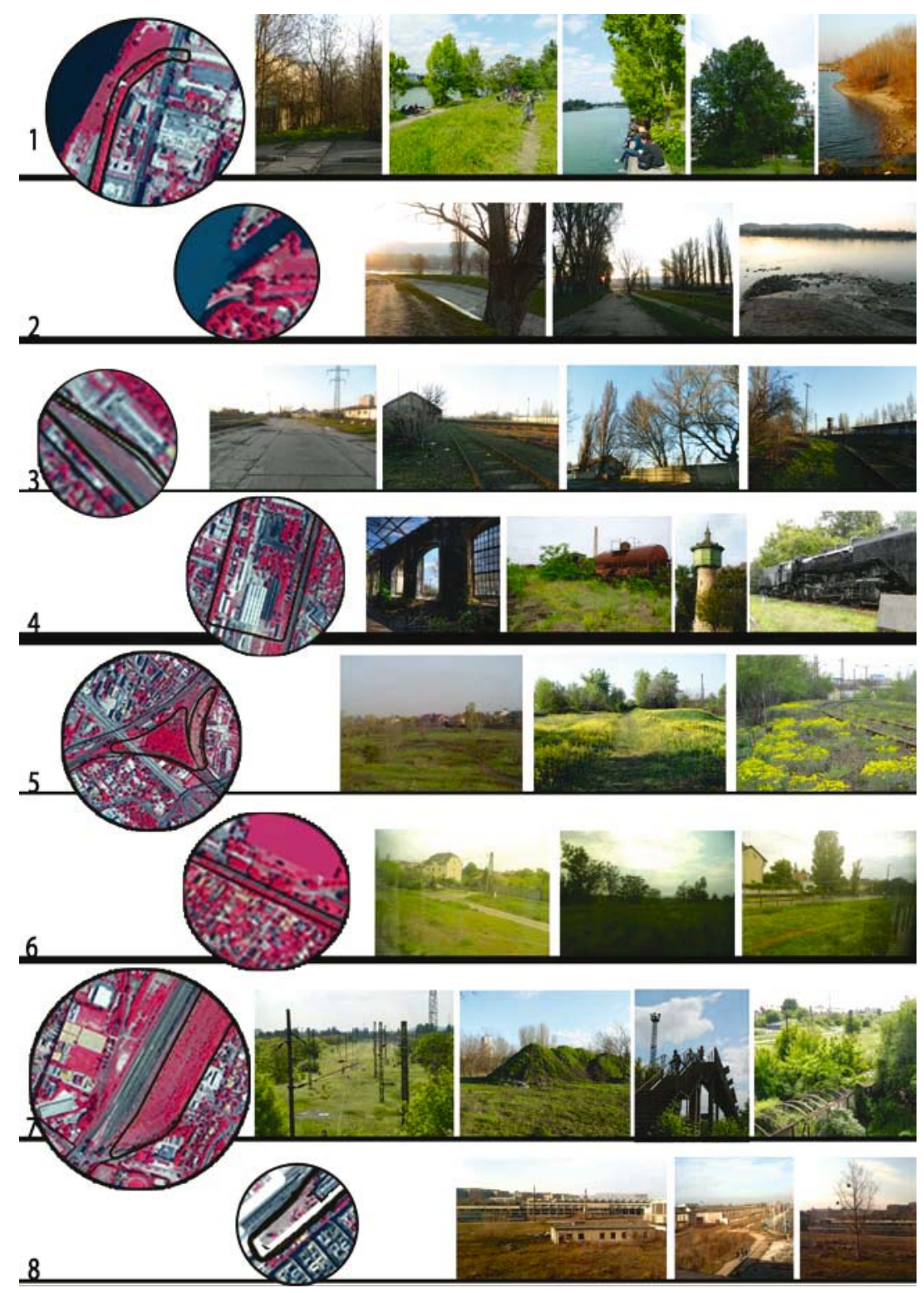

Fig. 6. Vegetation assessment along the northern railway trails (Hutter)

In general, we can conclude that on a slowly abandoned railway fallow, which is still under temporary use, a ruderal weed community is most likely to be established, while on those sites that have been completely abandoned (even if the former service facilities have remained behind), pioneering species would emerge. 
1. Vizafogó - abandoned railway line and former shipyard

The abandoned industrial trail remained undisturbed during the past decades allowing a wood vegetation to develop among the old tracks. From the mouth of Rákos Creek, along the slightly elevated creek bank and up to the overpass, a dense and occasional shrubbery vegetation follows the trail. Between the trail and the shore, a more diverse vegetation appears. Various patterns of large continuous grassland communities, smaller shrubberies and valuable solitaire trees are formed. The flood-plain grove by the Danube and the established wood vegetation on the massive concrete walls of the former shipyard have special significance. These two latter habitats and the tall railway 'alley' have unique characteristics and even recreational values.

2. Vizafogó - Rákos Creek and the surroundings of FOKA Bay

The Rákos Creek and its surroundings are one of the most significant linear green elements of the city. Even though the discharge of the creek is not substantial, the drainage basin covers most of the transitional and outer zones of the city. In the outer districts, it flows in the original riverbed in shorter-longer sections, but typically a concrete river bed is applied. This dominant, linear element "cuts into the urban fabric". Various green surfaces appear on both sides of the creek. Occasional stairs emerge from the green slopes by the creek, but mostly we can hardly get close to the water as it flows so deep below. Even though the water is deep beyond the area, it has a calm, soothing atmosphere and provides opportunity to relax. The green corridor along the creek is also valuable from recreational aspects, and the idea to transform it into a long green corridor connecting the nearby districts has already been included in several development plans. Probably the most important section of the creek is the mouth, where it flows into the Danube, running through an artificial riffle. The spit offers a scenic view over the whirling water and is also a shelter for birds and wildlife. It is a natural value of our city. The unique microclimate, the adjacent water and the sparse trees create an optimal habitat for the rich grassland community. The old Lombardy poplar alley by the creek enhances the linear spatial pattern.

\section{Angyalföld - railway station}

The established ruderal vegetation on the former station is a common example of a less valuable green surface that is usually developed on slowly abandoned railway sites through spontaneous succession process. Mostly large paved surfaces (the former loading areas and platforms), disused rails and the herbaceous plants create the typical stripe pattern. In the dense urban structure, these "empty" 
brownfields facilitate the ventilation of the nearby areas. Through minor but determined interventions (breaking off pavements, removing the leftover objects), these areas could be soon integrated into the urban green system. Eventually, the wood vegetation established along the former fence could accompany a new road or recreational path.

\section{Istvántelek - repair workhouse}

The former vehicle repair workhouse can be compared to a 'classical industrial rust area' in many ways. It is a densely built area and is a so-called 'train graveyard' preserving old railway memories. Due to the once conscious planning, today we can see remarkable and mature wood vegetation. The flourishing flora emerging from the former gardens dominate the site and the young saplings and offshoots also try to find their way on the abandoned site.

\section{Railway crossing, delta areas}

The areas created by the crossing railways are not typical railway rust areas. From an industrial and urban design perspective, they are not ideal for new building constructions. We can hardly find buildings or other facilities and premises on these sites where nature dominates. The succession processes are more or less progressive: we can observe clearings, ruderal vegetations, grooves and even dense forests formed by pioneering species with a vegetation index rate occasionally above $80 \%$.

\section{The railway ring}

The inter-station sections of the railway ring have resemblance to the abandoned site of Angyalföld Station. Its most valuable features are the kilometrelong sections and their unique morphology. Even though the mostly herbaceous vegetation among the rails is not significant, the green surfaces have evolved nicely on the empty sites during the past decades. By narrowing the former tracks and releasing rust areas, we could increase the green system and the urban green network. The different sections with various dimensions show different vegetation intensity. In case of a future railway corridor development, not only the demands for new road development should be considered but the idea of improving the green network. These sites should also be evaluated from the "greening" prospective based on their recreational values and their potential role in the green network. 


\section{Rákosrendező - railway transit station}

This abandoned railway transit station is one of the largest and complex reserve areas in Budapest. Various urban development concepts were already presented on its rehabilitation or reuse. So far, none of the functional or image concepts have taken into consideration the spontaneous vegetation that is established on the site (still owned by MÁV). From the near-infrared satellite image, it can be clearly seen that the vegetation is more evolved on the external trails, which were abandoned first. In the surrounding areas, we can also find a three-level vegetation with mostly pioneering species with significant canopy. Both the satellite images and the ground truthing confirm that during rehabilitation we need to take into consideration the spontaneous vegetation.

\section{Nyugati (Western) Railway Station}

The head station of the northern line experienced various changes. The industrial railway areas slowly became vacant and lost their functions. This was a long and ongoing process; therefore, only rudiments of the still developing vegetation can be observed. As a result of the constant activities, mainly ruderal (weed) communities could become established. There are only a few ornamental trees in the former service areas. The main potential of the 'railway fallow' is its central location and its extensive surface. The rust areas of the Nyugati Railway station are crucial for improving and enhancing a green system that serves good ventilation, air circulation.

In general, the urban development concepts do not consider the aspects of improving or enhancing the green network during a rust area revitalization. Making an example of the Vizafogó area, ${ }^{8}$ we will demonstrate how a general (or even "green-surface-improving") urban development project can relate to potentials held by the brownfields (Fig. 7). We have also chosen this particular area because District XIII has already prepared a strategic green area development plan uniquely in Budapest - $[15,16,17,18]$, and it is willing to create new green areas or renew the existing ones. However, in the case of the abovementioned railway corridor, it seems that when they prepared the long-term strategy they still did not try to exploit all the potentials of the brownfield areas. Budapest and District XIII recognize the importance of developing green corridors along the watercourses.

${ }^{8}$ Vizafogó is part of District XIII. After the demolition of the former Vizafogó Train Station, the old industrial tracks and the surrounding industrial sites mainly create residential areas (housing estates and new apartment houses) and transforming, redeveloping office buildings are erected. 
They also highlight the urban ecological and recreational objectives; however, from the development plan, we can draw these conclusions:

- According to the plan for road development (GREY), a new road would go along the railway line, crossing it at the northern end; consequently, the railway bridge crossing will need to be demolished and the nearby trees will be cut down.

- A considerable building construction is planned in the former shipyard area by the Danube-shore, developing both residential (ORANGE) and institutional (BLUE) buildings. As a consequence, the nearby trees along the rail line are also in danger. There would not be enough space left for the proposed ecological corridor. Moreover, the ecological and cityscapevalue of the flood-plain grove and its significance are not appreciated.

- The creek mouth will be even more loaded by the new, traverser road; the remaining green area is very small along the creek bed; notwithstanding the prominent value of the mouth (even on urban scale), the plan does not draw proper attention to it.

- The recreational route by the Danube is broken at FOKA Bay; the missing green network connection will be provided by the new roads in the new blocks (institutional and residential buildings).
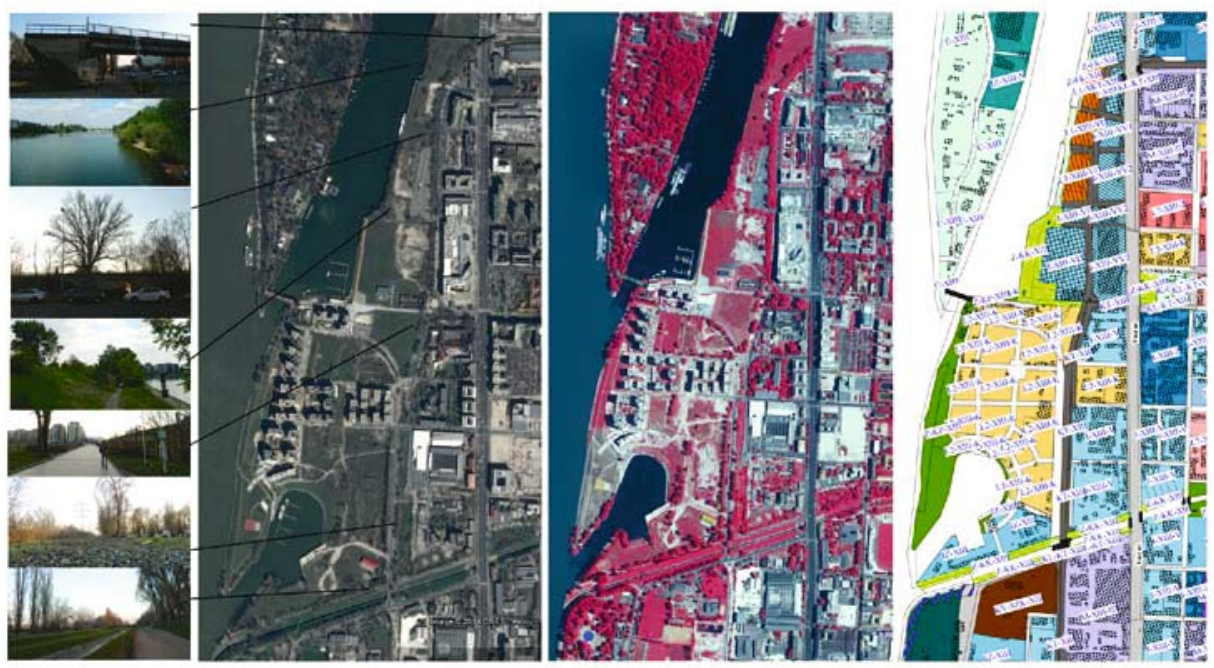

Fig. 7. Vizafogó - Photos, 2014 (Hutter); Orthophoto, 2010 (FÖMI); Near-infrared orthophoto, 2010 (FÖMI); Regulation plan (District XIII, 2009) 


\section{Results and conclusions}

The international overview also shows that the modern principles of sustainability and liveability would eventuate in land-saving, ecological means in urban development. Such a development will improve and enhance the urban green network and the urban green system. Unfortunately, the urban development concept of Budapest does not consider these aspects; it is rather influenced by economic or real estate development interests. Our research hypothesis is based on the finding that the urban structural and ecological features of the railway rust areas support the development of a well-structured green network and also improve the urban green system, thus ameliorating the environmental quality and the urban ecological conditions. This study presents the methodology of an ecologicallybased assessment and investigation for rust area revitalization. We are aware of the fact that urban ecology is only one of the various development objectives. The previously described methodology could be applied for including this aspect into future development concepts. Although a successful revitalization is based on a complex assessment, in this study, we did not consider the aspects of investment, market or economic interests. Our aim of discussing merely the urban ecological aspect was to raise attention to the importance of this neglected field.

We have compiled a table (see Tab. 3) to introduce the potential land uses, new functions along the rust areas by the northern railway lines. We can demonstrate how the rehabilitated railway areas can function in the urban green system of Budapest.

Tab. 3. Suggested new functions in the rust belt

\begin{tabular}{|c|c|c|c|}
\hline Num. & Name & Current function & Suggested function in the green system \\
\hline \multirow[b]{2}{*}{1} & \multirow[b]{2}{*}{ VIZAFOGÓ } & elevated industrial railway line & multilevel greenway, green corridor \\
\hline & & abandoned shipyard & $\begin{array}{l}\text { public open space with tree canopy, public park, } \\
\text { flood-basin forest, private garden with public } \\
\text { access }\end{array}$ \\
\hline \multirow{2}{*}{2} & RÁKOS CREEK & mouth & \multirow{2}{*}{$\begin{array}{l}\text { public park, greenway along waterfronts, } \\
\text { public institutional garden, sports field }\end{array}$} \\
\hline & FOKA BAY & water front & \\
\hline 3 & ANGYALFÖLD & railway station: abandoned trails & greenway, bicycle way, buffer forest belt \\
\hline 4 & ISTVÁNTELEK & repair workhouse & public institutional garden, public park \\
\hline 5 & DELTA & areas of railway network & buffer forest, public park, sports field \\
\hline 6 & RAILWAY RING & abandoned trails & greenway, bike way, buffer forest \\
\hline 7 & RÁKOSRENDEZÖ & transfer station & $\begin{array}{l}\text { green corridor, } \\
\text { buffer forest, public park, public institutional } \\
\text { garden }\end{array}$ \\
\hline 8 & NYUGATI & railway station: empty areas & green corridor, public park, sports field \\
\hline
\end{tabular}


Finally, a schematic map (see Fig. 8) will demonstrate the network of the proposed optimal developmental directions: the new greenways and green corridors. The linear green elements - supporting the major nodes - complete the current urban green system.

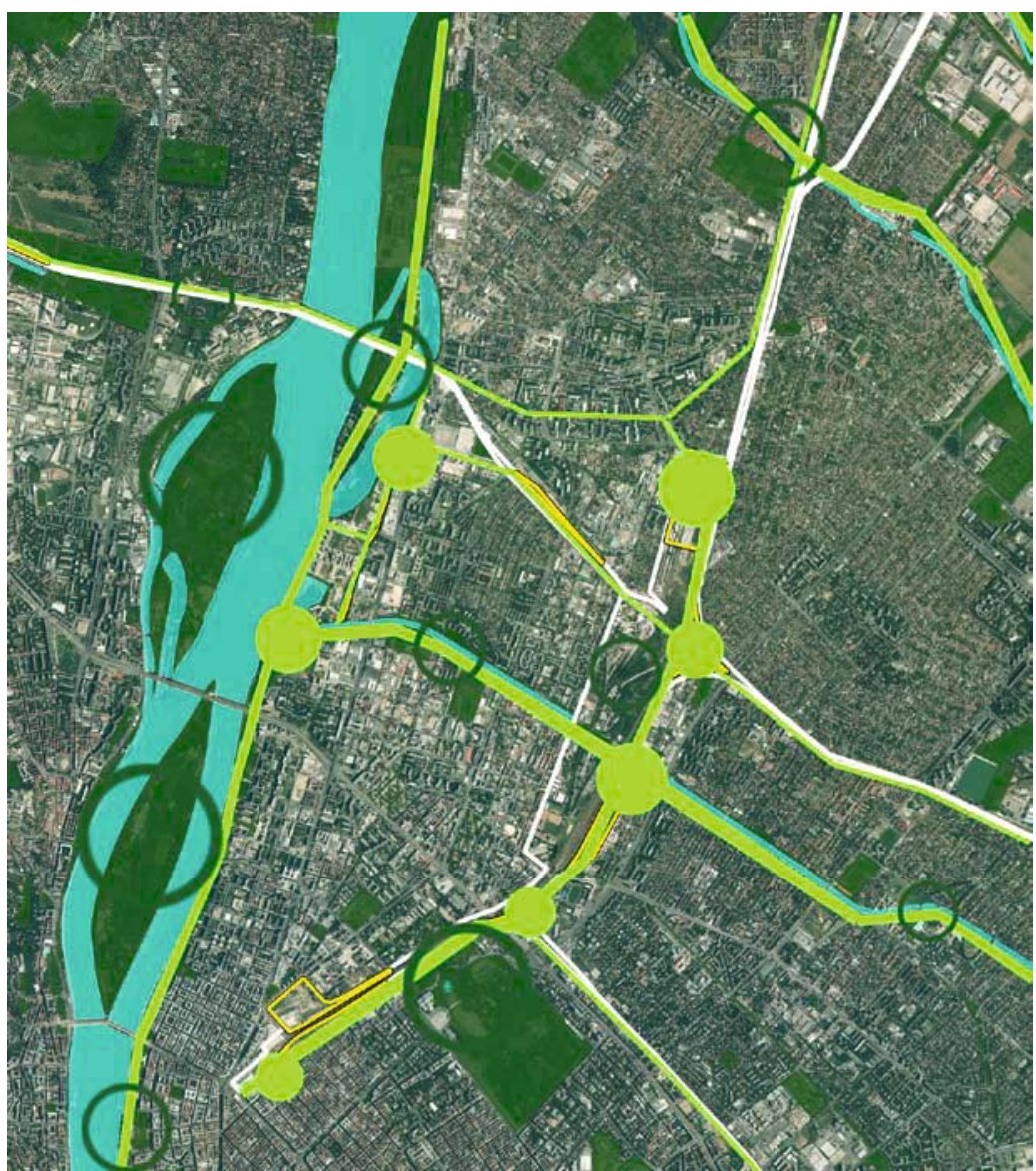

Fig. 8. The schematic map represents the improvement of the green network through railway rust area rehabilitation (Hutter)

In the urban environment, it is rather difficult to create new greenways, but, as the schematic map illustrates, through conscious and long-term planning, we can improve the ring-radial urban green system and create recreational opportunities within the urban area. 


\section{References}

[1] Szilágyi, K., Almási, B., Hutter, D., Szabó, L. (2012), A várostervezés szürke - zöld dilemmái. TÁMOP Élhető települési táj. Összefoglaló tanulmányok, BCE, Budapest, vol. 1: 205-226.

[2] Mőcsényi, M. (1973), Zöldfelület-politikai elvek meghatározása egyes szabályozást igénylö kérdések megoldásához. Szakosított városgazdálkodási képzés, Zöldfelületgazdálkodás. ÉVM Továbbképző Központ, 1973-74.

[3] Jombach, S. (2012), Térségi vagy települési szintű zöldfelület-intenzitás távérzékelési elemzésének módszere. Tájépitészeti és Kertmüvészeti Folyóirat Különszám, 219-232.

[4] Beluszky, P., Györi, R. (2004), A budapesti barnaövezet határai. In: Barta, Gy.: A budapesti barnaövezet megújulási esélyei. Budapest, MTA, 71-74.

[5] Almási, B. (2006), Zöld mustra. Tájépitészeti és Kertmüvészeti Folyóirat 2, 1-9.

[6] De Sousa, C. A. (2002), Brownfield redevelopment in Toronto: an examination of past trends and future prospects. Land Use Policy 19, 297-309.

[7] De Sousa, C. A. (2003), Turning brownfields into green space in the City of Toronto. Landscape and Urban Planning 62, 181-198.

[8] Balogh, P. I. (2004), A szabadterek szerepváltozása a nagy európai városmegújításokban (PhD dissertation), Budapesti Corvinus Egyetem.

[9] Heathcott, J. (2013), The Promenade Plantée - Politics, planning, and urban design in postindustrial Paris. Journal of Planning Education and Research 33(3), 280-291.

[10] Byrne, J., Sipe, N. (2010), Green and open space planning for urban consolidation - A review of the literature and best practice. Urban Research Program. Issues Paper 11. March 2010. Griffith University.

[11] Barta, Gy. (ed.) (2004), A budapesti barnaövezet megújulási esélyei. Budapest, MTA.

[12] Löcsei, H. (2002), A budapesti rozsdaövezet problémás területei. Interjúsorozat kerületi fóépítészekkel (2002. június-július), MTA Regionális Kutatások Központja, Budapesti Osztály.

[13] Gábor, P., Jombach, S., Ongjerth, R. (2006), Budapest zöldfelületi állapotfelmérése ürfelvételek feldolgozásával. Tájépitészeti és Kertmüvészeti Folyóirat 4, 15-22.

[14] Gábor, P., Jombach, S., Ongjerth, R. (2007), A biológiai aktivitás változása Budapesten és a Budapesti Agglomerációban 1990-2005 között. Tájépitészeti és Kertmüvészeti Folyóirat 5, 21-28.

[15] Angyalföld Budapest (2008), Budapest XIII. kerületi Önkormányzat zöldfelület fejlesztési koncepciója és zöldhálózat fejlesztési programterve. XIII. kerületi Környezetgazdálkodási Nkft, Zöldfácska Kft., head planner: Gábor Péter

[16] Szilágyi, K. (2011), From environmentalism to liveable urban landscape. In: Benkő, M., Szabó, Á.: Essays on urban design/Városépítészeti tanulmányok. BME Urbanisztika Tanszék, Budapest, 26-35.

[17] Szilágyi, K. (2003), A zöldterülettől a zöldfelületi és szabadtér rendszerig. Ormos Imre Emlékülés kiadványa, Budapest.

[18] Hutter, D. (2012), Budapest zöldfelületi rendszerének megújítása barnamezős területek rehabilitációjával. In: Élhető Települési Táj Tudományos Közlemények és Értekezések, Budapesti Corvinus Egyetem, 53-162. 